\title{
Issues in Review
}

Christopher Highley (Contributing Editor), Christi Spain-Savage, Roze Hentschell, and Rebecca Tomlin

\section{Theatre and Neighbourhood in Early Modern London}

\section{Introduction: Exploring Neighbourhoods}

Christopher Highley

Early Theatre 19.2 (2016), 157-166

http://dx.doi.org/10.12745/et.19.2.2858

This essay summarizes scholarship about the neighbourhoods and parishes surrounding London's early modern theatres, and in the process introduces three essays for the Early Theatre Issues in Review 'Theatre and Neighbourhood in Early Modern London'.

Several decades ago, William Ingram embarked on a project to reconstruct the neighbourhoods around London's Bankside theatres by examining the unusually rich legal and parochial records of Southwark, and in particular the Communion Token Books from the parish of St Saviour. Ingram's ongoing work (in collaboration with Alan H. Nelson) reveals the residential patterns around the Rose, Swan, and Globe theatres before and after they were built, helping us to understand their impact on the economic, social, and cultural life of their locales. Ingram has found that the construction of public playhouses like the Swan did not, as once assumed, signal the deterioration of their surrounding neighbourhoods and the onset of community blight. The erection of a playhouse did not necessarily lead nearby residents to move away: in fact, it may have attracted new residents or stimulated the construction of new housing. ${ }^{1}$

Ingram and Nelson's painstaking archival work has now reached a wider audience thanks to an online presence, ${ }^{2}$ but until recently their approach had little influence on other theatre historians interested in the cultural geography of early

Christopher Highley (highley.1@osu.edu) is a professor in the department of English at the Ohio State University. 
modern playing. Their work, for example, barely registers in Steven Mullaney's highly influential Place of the Stage, a book that took an anthropological rather than social-historical, data-driven approach to the question of why playhouses appeared where they did in the urban landscape and how they shaped and were shaped by that landscape. ${ }^{3}$ Only in the last few years have Mullaney's claims about a physically marginal and ideologically oppositional theatre been challenged by scholars like Mark Bayer, whose Theatre, Community, and Civic Engagement in Jacobean London argues that the histories of northern playhouses like the Red Bull and Fortune are best understood in the context of the economic, social, and cultural life of their immediate neighbourhoods. ${ }^{4}$ Bayer rejects seductive generalizations about theatre's territorial marginality as well as simplistic oppositions that contrast a supposedly well-governed and orderly City with the disorderly suburbs beyond the ancient walls. Incorporating the latest scholarship by urban sociologists and historians of early modern London like Ian Archer, Vanessa Harding, and Joseph Ward, Bayer's book is a blueprint for new work on the entanglement of playhouses in the world immediately beyond their walls. ${ }^{5}$ Bayer's work explains, for example, how the Red Bull and Fortune operated not for the benefit of a London-wide audience but for the residents in their immediate catchment area. For these playhouses to be successful, the kinds of plays they staged had to be tailored to the limited educational horizons and cultural expectations of the local population, which comprised mostly low-skilled workers with little formal education.

How do we define a theatrical neighbourhood in early modern London? In one sense, the metropolis was a single theatrical neighbourhood in which people from across the capital were, in theory, free to patronize its many far-flung playhouses. From early on, however, playhouses clustered in two distinct areas: north of the City in the suburbs of Clerkenwell and Shoreditch, and on the Bankside, or what one of John Donne's narrators calls the 'Thames' right side', whose inhabitants scorn 'London's Mayor'. Donne's designation defines the Bankside in terms of what he perceives to be its prevailing social attitudes, especially opposition to the jurisdiction of the corporation of London. In so doing, he elides and subsumes the patchwork of administrative entities of parish, ward, manor, borough, and county that made up the area within a single imagined cultural territory. ${ }^{6}$

Still, writing the history of a theatrical neighbourhood requires us to take into account the official jurisdictional spaces like the parish that held sway over a playhouse. In the case of the Swan, Ingram shrinks the scope of neighbourhood even further to encompass only 'a small area, lying within two hundred yards of the playhouse'. 7 This is a useful if arbitrary measure, but it is also helpful to think 
of a theatre's neighbourhood more expansively as the area that supplied playgoers, actors, and other personnel, as well as materials for daily operations (like candles for indoor theatres) and for maintaining the physical fabric of the playhouse like timber and tiles. In other words, we need to keep multiple definitions of neighbourhood in mind at the same time - ones that acknowledge official boundaries as well as others that reflect the personal and idiosyncratic ways in which early modern Londoners drew their mental maps. Like all forms of neighbourhood, theatrical neighbourhoods were imaginary constructs that held special meaning for individuals: they began and ended where people believed they did, and as such they were liable to change in both size and shape. ${ }^{8}$

In some cases, though, the city's physical geography and built environment constrained the ways Londoners conceptualized theatrical neighbourhoods. Paul's playhouse — the subject of Roze Hentschell's essay — was part of the great cathedral that occupied its own compound separated from the adjacent city by encircling walls, buildings, and gates that closed each evening. The Blackfriars indoor playhouse, located to the immediate southwest of Paul's, also belonged to a self-evident, because physically-enclosed, neighborhood. Covering approximately five acres, the Blackfriars was bounded to the south by the Thames, to the west by the Fleet River, and to the north and east by a combination of City and precinct walls punctuated by gates that opened and closed daily. The Blackfriars' status as an ex-ecclesiastical liberty led residents and outsiders alike to perceive that this part of London was an autonomous enclave within the surrounding City. Residents of the liberty laid claim to special privileges (inherited from the Dominican monks) that freed them from certain civic taxes and responsibilities. Defence of these privileges promoted a strong sense of communal identity among residents, some of whom signed leases requiring them to uphold the traditional liberties of the Blackfriars against the interference of the lord mayor and his officers. From time to time trouble arose when City or guild officials (who regularly appealed to the crown for control over the liberty) entered the precinct without permission from its leading residents. Yet no one questioned the boundaries of the Blackfriars precinct or the perimeter of its urban footprint that was coextensive with the parish of St Anne, Blackfriars.

What sorts of questions might frame a study of the relationship between the Blackfriars theatre and its surrounding neighbourhood? We would first want to know why Richard Farrant (lessee of the rooms in the old monastery building that he turned into the first Blackfriars theatre in 1576) and James Burbage (lessee of a different suite of rooms that he converted into the second in 1596) chose this location. The proximity and accessibility of the area to potential playgoers was a 
crucial factor, but did the Blackfriars' status as a liberty also make it attractive? If Burbage thought he could avoid civic opposition by building his playhouse inside the walls of London but outside the control of the mayor, he was soon to discover otherwise. No sooner had he converted the rooms in question than a group of leading Blackfriars residents successfully petitioned, not the City, but the Privy Council to keep the new theatre dark. And yet, the aristocrats, businessmen, and clergy who successfully blocked Burbage's theatre from opening in 1596 on the grounds it would be a social nuisance did not necessarily speak for all the residents of the area. Some notable residents did not sign the petition, suggesting perhaps that the prospect of a theatre divided local opinion. Over the course of the next forty-five years, the second theatre in the Blackfriars appears to have stirred mixed emotions among its neighbours, as well as conflicting responses within individuals.

The anti-theatrical lobby of 1596 succeeded in its immediate objective, but just four years later Burbage transferred his lease to Henry Evans, whose company of boy actors began performing in late 1600 . This time there was no petition, nor did opponents of playing mobilize in 1608 when Burbage's heirs regained the lease and after a short hiatus reopened the playhouse with the adult actors of the King's Men. In fact, it was not until 1619 that residents again petitioned for the closing of the theatre on grounds of public nuisance. The appearance or non-appearance of petitions against the playhouse provides a useful way into investigating relations between playing and the neighbourhood community in this corner of London. That no petition was organized by residents to block Evan's plans in 1600 raises several questions. Were the same people who had initially protested Burbage's plans to install a company of adult actors less worried about the presence of boy players? Performances by child actors may have seemed less threatening and more in keeping with local tradition, since Farrant's earlier theatre had employed only choir boys from the chapel royal. Another possibility is that the local circumstances in which the 1596 petition was produced had changed dramatically: signatories might have died, moved from the district, or otherwise disengaged from community life. In fact, none of the names on the 1596 petition reappeared on that of 1619 , which is also signed by fewer aristocrats and gentry and bears the names of many more obscure or untraceable residents, including several widows.

Once playing began at the second Blackfriars theatre in 1600, local attitudes and prejudices were liable to change. The area now attracted up to 500 playgoers at least once a week, some from inside, others from outside the precinct. ${ }^{9}$ No doubt, the convergence of so many bodies in and around the playhouse proved 
an inconvenience to some neighbours. The 1596 petition had predicted that playgoers would crowd and obstruct the streets, bringing noise, disease, and disorder. And, looking back over the past two decades, the 1619 petition claimed this is exactly what had happened. At the same time, however, the regular influx of playgoers would have stimulated the local economy, brought trade to established eating and drinking establishments, and employed hucksters and street vendors. High-end businesses like goldsmiths, jewelers, and watch makers, of which there were plenty in Blackfriars, could also have benefitted from the presence of affluent playgoers, many drawn from the orbit of the royal court and the nearby law schools in Holborn. Blackfriars was equally well known for its feather-dressers or plumiers (figures of ridicule in the plays of the period), men like Owen Lochard (who possibly supplied the sartorial needs of the gentlemen gallants at the indoor playhouse), as well as the tiremen and women responsible for equipping the actors. $^{10}$

Especially after 1608 when adult actors displaced the children, theatre people would have been a regular sight on the streets of Blackfriars. They were no longer dangerous outsiders in the eyes of once-suspicious residents, but neighbours, customers, fellow parishioners, and ratepayers. Residents grew accustomed to theatre professionals among them. Ben Jonson, for example, was living in the precinct off and on from 1605, baptizing and burying his children at St Anne's.

But what of the godly clergy who dominated St Anne's pulpit in the later sixteenth and seventeenth centuries? The popular Blackfriars preacher Stephen Egerton signed the 1596 petition, just as his equally fervent successor, William Gouge, signed in 1619. Why, given that the church of St Anne's was only a few hundred feet from the theatre, did these supposedly anti-theatrical divines not protest more vigorously? Apart from a few references in their printed sermons to the dangers of playgoing, Egerton and Gouge were quite restrained on the topic, reluctant perhaps to alienate those parishioners who attended plays or whose livelihood benefitted from the theatre. Of course, the presence of a playhouse in such a strongly Puritan-identified parish like St Anne's also offered the godly a heaven-sent example on their own doorstep of a den of iniquity and of the kind of temptation that God-fearing Londoners ought to shun. In other words, the local theatre could serve the rhetorical purposes of the godly, especially at moments when invective against the reprobate/wicked took precedence over more inclusive and conciliatory gestures. ${ }^{11}$ For the most part, though, Egerton and Gouge chose not to attack the playhouse directly; instead, they shifted the focus to the individual parishioner and potential playgoer, whose responsibility was to resist the seductive appeal of the stage. ${ }^{12}$ 
I have begun to suggest that there is much to gain by examining the webs of economic, social, and cultural connections between playhouses and their neighbourhoods. But did plays themselves engage critically with the neighbourhoods in which they were first performed? In the case of the second Blackfriars theatre, Ben Jonson's Alchemist (1610) suggests that sometimes they did. The Alchemist, in fact, may have been written by Jonson to launch the King's Men's tenancy of their new winter house. Jonson continually reminds his first audiences that the staged action is happening not just in the Blackfriars precinct, but in a room inside a house in that precinct - a room of wonders and illusions very like that in which the spectators are sitting. Jonson metatheatrically positions that audience as analogous to the 'sober, scurvy, precise neighbors' who surround Lovewit's house on stage at the end of the play (1.1.165). It's no coincidence given the prominence of Egerton and Gouge (who first appears in Blackfriars as Egerton's temporary substitute in summer 1608) in the precinct, as well as its reputation as a Puritan enclave, that Jonson uses the play to stir discussion of religious controversy. The play's two religious zealots, the Anabaptists Ananias and Tribulation Wholesome, seem designed to elicit comparison with the likes of Egerton and Gouge. How spectators responded to this invitation is unclear: some, recognizing the characters as religious separatists living in exile, and committed to the destruction of the church of England, were no doubt reassured by the wide ideological gap separating them from 'respectable' London Puritans like Egerton and Gouge. Less discriminating spectators, however, might construe Ananias and Tribulation as dangerous manifestations of what the nonconformity of preachers like Egerton and Gouge could turn into or help promote if left unchecked. ${ }^{13}$

Christi Spain-Savage's essay on early performances of A Chaste Maid in Cheapside at the Swan playhouse on the Bankside also shows how plays can engage the very neighbourhoods in which they are staged. Spain-Savage argues that Chaste Maid takes up the cause of the watermen who lived close to the Swan and whose livelihood depended on ferrying playgoers back and forth across the Thames. Although most of the action in the play takes place around Cheapside, Middleton's dialogue as well as the appearance on stage of several watermen characters implicitly lodges support for an industry in crisis following the burning of the Globe and the recent closing of other Bankside entertainment venues. As theatrical activity shifted from south of the river to city liberties like Blackfriars and to the northern suburbs, the playing company at the Swan had every reason to make common cause with the impecunious watermen. 
Hentschell's essay on Paul's playhouse examines its immediate surroundings through the same kind of lens I have used for the Blackfriars. She too stresses the ways in which the theatre was woven into the religious fabric of the neighbourhood and how it contributed to perceptions of the cathedral precinct in general. Her analysis of the boy choristers - who performed in what was by all accounts a tiny playing space - provides a localized focus for broader critical conversations about the relationship between the sacred and the secular in early modern London. Hentschell finds that the multiple subject positions occupied by the boys were made possible by and contributed to the ultimate inseparability of sacred and secular space and behavior inside the cathedral precinct.

Rebecca Tomlin's essay is less about actual theatrical neighbourhoods or their representation on stage than about the way plays explore the concept of neighbourhood and how meaningful spaces might be constructed and experienced by dramatic characters and their real-life counterparts. Her essay focuses on the defining urban practice of walking in A Warning for Fair Women and Edward IV. Tomlin shows how characters create neighbourhoods by walking certain routes, thereby — in Michel de Certeau's terms — converting abstract space into meaningful place or lived territory. Tomlin argues that by repeatedly travelling familiar routes while on business or as part of other authorized routines, characters transform public space into their private networks. On the other hand, characters who walk without purpose or who travel routes unbecoming their occupation or rank threaten neighbourhood identity and the sense of belonging it confers.

In early modern England, the idea of belonging to a geographically restricted, face-to-face, community in which neighbourliness was a guiding principle was important not just to an ideology of social order but to the deepest ways in which people conceived of themselves and others. In our own world of easy travel, longdistance communications, and personal mobility, we tend to lose sight of how physically circumscribed were the lives of most early modern people. ${ }^{14}$ The urban experience of London's extraordinary growth from the mid-sixteenth century in large measure helped transform a sense of the individual's relation to space and the possibility of movement within and beyond it. As London grew into a collection of micro-communities, it also became a centre of a network of global commerce connecting the far-flung parts of a nascent empire. Scholars of early modern drama have, for the past few decades, followed the routes of this network, looking beyond the horizons of the Atlantic archipelago to the Mediterranean, the east, the orient, the new world, and to countless other locales to help make sense of the period's cultural products. We need to remember, though, that the actual stages upon which these non-English and often non-western cultures were 
imaginatively brought to life were located in specific urban neighbourhoods neighbourhoods that shaped and were shaped by the commerce of theatre and the experience of playgoing.

\section{Notes}

1 William Ingram, "Neare the Playe howse": The Swan Theater and Community Blight', Renaissance Drama 4 (1971), 53-68; 'The Globe Playhouse and its Neighbours in 1600', Essays in Theatre 2.2 (1984), 63-72.

2 Alan H. Nelson and William Ingram, The Parish of St Saviour, Southwark, http:// www-personal.umich.edu/-ingram/StSaviour/.

3 Steven Mullaney, The Place of the Stage (Chicago, 1988).

4 Mark Bayer, Theatre, Community, and Civic Engagement in Jacobean London (Iowa City, 2011). Also see Alan Somerset, 'Cultural Poetics or Historical Prose?', Medieval and Renaissance Drama in England 11 (1999), 34-59.

5 Ian W. Archer, The Pursuit of Stability: Social Relations in Elizabethan London (Cambridge, 1991); Vanessa Harding, The Dead and the Living in Paris and London, 1500-1670 (Cambridge, 2002); Joseph P. Ward, Metropolitan Communities: Trade Guilds, Identity, and Change in Early Modern London (Stanford, 1997).

6 Donne, 'Elegie 1', Poems (London, 1633), 45.

7 Ingram, 'Blight', 63.

8 Julie Sanders, The Cultural Geography of Early Modern Drama, 1620-1650 (Cambridge, 2014), esp. chapters 5 and 6 .

9 The capacity of the playhouse and frequency of performances are matters of debate. See Irwin Smith, Shakespeare's Blackfriars Playhouse: Its History and Design (New York, 1963), 258-9, 296-7.

10 London Subsidy Roll, 1599 (http://socrates.berkeley.edu/ ahnelson/SUBSIDY/390a. html); will 1604 (National Archives рRов 11/103/284).

11 Gouge's funeral elegist called him 'a justice of peace as well as a minister of peace', a figure of respect in the community who could reconcile neighbourly differences and bring concord (William Jenkyn, A Shock of Corn [London, 1654], 43).

12 See the excellent discussion of Egerton's 'bruising regimen of self-incriminating introspection, which he described as "Christian clearing"' in Peter Iver Kaufman, Religion Around Shakespeare (Pennsylvania, 2013), 123-6.

13 See Irvonwy Morgan, The Godly Preachers of the Elizabethan Church (London, 1965), 33-57. On people who claim to become separatists after attending Egerton's 
lectures, see Peter Lake, Moderate Puritans and the Elizabethan Church (Cambridge, 1982), 78.

14 Keith D.M. Snell, Parish and Belonging: Community, Identity, and Welfare in England and Wales, 1700-1950 (Cambridge, 2006). Although this book deals with a later period, its core insights also apply to the early modern era. 
